\title{
ANALISIS KESANTUNAN BERBAHASA PADA TAJUK RENCANA HARIAN SUARA MERDEKA DAN RELEVANSINYA SEBAGAI BAHAN AJAR MENULIS TEKS EDITORIAL SISWA KELAS XII SMA
}

\author{
Mutiah Ariska Putri' ${ }^{1}$, Kundharu Saddhono², Budi Waluyo ${ }^{3}$ \\ Universitas Sebelas Maret \\ Email: mutiahariskaputri1@gmail.com ${ }^{1}$, kundharu.uns@gmail.com², \\ mas_bewe@yahoo.co.id ${ }^{3}$
}

\begin{abstract}
Abstrak: Penelitian ini bertujuan untuk mendeskripsikan dan menjelaskan: (1) pematuhan kesantunan dan pelanggaran kesantunan berbahasa pada tajuk rencana harian Suara Merdeka; (2) fungsi kesantunan berbahasa pada tajuk rencana harian Suara Merdeka; (3) relevansi kesantunan berbahasa pada tajuk rencana harian Suara Merdeka sebagai bahan ajar menulis teks editorial siswa kelas XII SMA. Penelitian ini berupa deskriptif kualitatif dengan menggunakan metode analisis isi. Sumber data yang digunakan pada penelitian ini berupa dokumen, yaitu tajuk rencana harian Suara Merdeka dan informan. Hasil penelitian sebagai berikut. (1) pematuhan kesantunan berbahasa yang paling banyak ditemukan adalah maksim kesimpatian, sedangkan yang paling sedikit ditemukan adalah maksim kesederhanaan. Pada pelanggaran kesantunan berbahasa yang paling banyak ditemukan adalah maksim penghargaan, sedangkan yang paling sedikit ditemukan adalah maksim pemufakatan; (2) fungsi kesantunan berbahasa yang paling banyak ditemukan adalah fungsi menyatakan, sedangkan yang tidak ditemukan sama sekali adalah fungsi meminta maaf; (3) analisis kesantunan berbahasa pada tajuk rencana harian Suara Merdeka relevan jika dijadikan sebagai bahan ajar menulis teks editorial siswa kelas XII SMA.
\end{abstract}

Kata Kunci: analisis kesantunan, teks editorial, bahan ajar

\section{POLITENESS ANALYSIS ON EDITORIAL TEXT "SUARA MERDEKA" DAILY AND ITS RELEVANCE AS TEACHING MATERIALS ON EDITORIAL TEXT WRITE FOR $12^{\text {th }}$ GRADE STUDENTS OF SENIOR HIGH SCHOOL}

\begin{abstract}
The purpose of this research are to describe and explain: (1) compliance with modesty and politeness infringement on editorial Suara Merdeka daily; (2) the function of politeness in Suara Merdeka daily editorials; (3) the relevance of politeness in Suara Merdeka daily editorial resource as text editorial writing class XII student in high school. This research is a qualitative descriptive by using content analysis method. The data used in this study of the document, namely Suara Merdeka daily editorial and informants. The result show that (1) compliance politeness of the most prevalent is the sympathy maxim, while the least was found is the maxim of simplicity. On offense politeness most common is the maxim of the award, while the least was found is the maxim of agreement; (2) the function of politeness most common is the function stated, while that is not found at all is a function of apology; (3) analysis of politeness in Suara Merdeka daily editorial relevant if used as teaching material writing editorial texts for $12^{\text {th }}$ grade students of senior high school.
\end{abstract}

Keywords: analysis of politeness, editorial text, teaching material.

BASASTRA Jurnal Bahasa, Sastra, dan Pengajarannya

Volume 8 Nomor 2, Oktober 2020, P-ISSN 2302-6405, E-ISSN 2714-9765 


\section{PENDAHULUAN}

Bahasa merupakan sebuah sarana yang digunakan oleh setiap orang untuk berkomunikasi baik secara lisan maupun tulisan. Kemampuan berkomunikasi yang dimiliki oleh setiap orang sangat bervariasi. Proses komunikasi tersebut membutuhkan bahasa sebagai sarana untuk mencari informasi atau memberikan informasi kepada orang lain. Penggunaan bahasa sebagai alat komunikasi lisan maupun tulisan harus sesuai dengan aturan agar tidak merugikan penutur maupun lawan tutur. Tampaknya pemakaian bahasa secara santun belum banyak mendapat perhatian. Oleh karena itu, sangat wajar jika kita sering menemukan pemakaian bahasa yang baik ragam bahasanya dan benar tata bahasanya, tetapi nilai rasa yang terkandung di dalamnya menyakiti hati pembaca atau pendengarnya (Pranowo, 2012:4).

Pragmatik merupakan salah satu cabang ilmu linguistik yang mempelajari tentang makna dalam suatu ujaran yang terikat konteks. Dalam kegiatan sehari-hari tentunya setiap orang saling berinteraksi dalam berbagai hal. Berhubungan dengan hal itu, tidak dapat dipungkiri bahwa sering terjadi kesalahan dalam berkomunikasi antara penutur dan lawan tutur. Maka dari itu, setiap orang perlu memahami konteks untuk dapat berkomunikasi dengan baik. Berkaitan dengan pengertian pragmatik, Rahardi (2005: 50) menyatakan bahwa pragmatik mengkaji maksud penutur dalam menuturkan sebuah satuan lingual tertentu pada sebuah bahasa.

Salah satu kajian pragmatik adalah kesantunan berbahasa. Kesantunan berbahasa yang digunakan oleh setiap orang dalam menyampaikan tuturan erta kaitannya dengan martabat dan harga diri masing-masing. Ketika setiap orang dapat berbahasa dengan santun, maka martabat diri di hadapan umum sudah pasti akan lebih dihargai. Berbahasa yang dimaksud baik secara lisan maupun bahasa tulis. Pernyataan tersebut sesuai dengan pendapat Brown dan Levinson (dalam Chaer, 2010: 11) teori tentang kesantunan berbahasa itu berkisar atas nosi muka atau wajah (face) dalam "citra diri" yang bersifat umum dan selalu ingin dimiliki oleh setiap anggota masyarakat. Selain itu, Rahardi, dkk. (2018: 67) menyatakan bahwa kesantunan suatu tuturan tidak hanya dilihat dari bentuk-bentuk kebahasaannnya, yang lazim pula diidentifikasi sebagai penandapenanda kesantunan, tetapi juga dapat dicermati dari cara orang menyampaikan maksud sopan atau santunnya itu.

Pengkajian kesantunan berbahasa memang perlu dilakukan untuk mengetahui pematuhan kesantunan berbahasa dan penyimpangan kesantunan berbahasa yang tejadi dalam proses komunikasi. Hasil penelitian Mustika (2013) yang menyatakan bahwa mentradisikan kesantunan berbahasa melalui 
lingkungan pendidikan formal maupun informal merupakan upaya yang harus dilakukan untuk menyiapkan generasi bangsa yang berkarakter.

Hasil penelitian kesantunan berbahasa dapat dijadikan acuan oleh setiap orang dalam berkomunikasi secara baik, benar, dan santun. Hal tersebut sesuai dengan hasil penelitian Mahmud, Abduh, dan Akil (2019) berjudul "Promoting a balance of harmony and authority in Indonesian research seminars through politeness strategis" yang menyatakan bahwa speaker dalam seminar penenelitian menerapkan berbagai strategi dalam mengungkapkan kesantunan, seperti menjadi perhatian, menggunakan penanda identitas, menggunakan pidato asli, mencapai kesepakatan, berbicara bercanda, menjadi tidak langsung, meminta kejelasan, dan mengekspresikan penyesalan. Dapat diketahui bahwa dalam hasil penelitian tersebut seorang speaker berbicara dengan menjaga kesantunan untuk meminimalkan konflik dan menciptakan suasana yang harmoni.

Pelanggaran prinsip kesantunan berbahasa juga ditemukan pada tajuk rencana Online harian Suara Merdeka pada hari Rabu tanggal 11 September 2019. Tajuk rencana pada hari tersebut membahas mengenai

"Pengoptimalan Penguasaan Enam Literasi." Pembahasan tersebut tentu memiliki daya tarik tersendiri bagi kaum intelektual, terutama dalam bidang kependidikan sehingga sebaiknya bahasa yang digunakan harus santun. Namun, terdapat sebuah pernyataan yang merupakan bentuk pelanggaran kesantunan berbahasa "Siapa yang bertanggung jawab mengoptimalkan penguasaan enam literasi dasar? Tentu saja yang utama pemerintah." Pernyataan tersebut merupakan pelanggaran salah satu maksim menurut prinsip Leech, yaitu maksim pemufakatan atau kecocokan, karena pada jawaban atas pertanyaan tersebut penulis memaksimalkan ketidakcocokan dengan pemerintah. Di mana dalam maksim kecocokan, menggariskan setiap penutur dan lawan tutur untuk memaksimalkan kecocokan di antara keduanya. Selain itu, penulis secara langsung memojokkan lawan tutur dalam bertutur. Dengan adanya hal tersebut, komunikasi secara tertulis masih banyak ditemukan penggunaan bahasa yang kurang santun sehingga menimbulkan makna rancu, sulit dipahami, dan merugikan mitra tutur. Padahal seharusnya setiap orang diharapkan mampu berbahasa dengan santun

Leech (2011: 206-207) menyatakan bahwa terdapat prinsip kesantunan meliputi enam maksim, yaitu maksim kebijaksanaan, maksim kedermawanan, maksim penghargaan, maksim kesederhanaan, maksim pemufakatan, dan maksim kesimpatian. Penjelasannya sebagai berikut. (1) Gagasan dasar maksim kebijaksanaan dalam prinsip kesantunan berbahasa adalah bahwa 
para peserta pertuturan hendaknya berpegang pada prinsip untuk selalu mengurangi keuntungannya sendiri dan memaksimalkan keuntungan pihak lain dalam kegiatan bertutur; (2) Maksim kedermawanan atau maksim kemurahan hati, para peserta pertuturan diharapkan dapat menghormati orang lain; (3) Maksim penghargaan memiliki aturan bahwa orang akan dapat dianggap santun apabila dalam bertutur selalu berusaha memberikan penghargaan kepada pihak lain; (4) Maksim kesederhanaan atau maksim kerendahan hati memiliki aturan bahwa peserta tutur diharapkan dapat bersikap rendah hati dengan cara mengurangi pujian terhadap dirinya sendiri; (5) Maksim pemufakatan memiliki aturan bahwa ditekankan agar para peserta tutur dapat saling membina kecocokan atau kemufakatan di dalam kegiatan bertutur; (6) Maksim kesimpatian memiliki aturan yang mengharapkan agar para peserta tutur dapat memaksimalkan sikap simpati antara pihak yang satu dengan pihak lainnya.

Selain prinsip kesantunan, terdapat fungsi kesantunan yang dilihat dari pihak penutur, terbagi menjadi lima fungsi, yaitu fungsi menyatakan (deklaratif), fungsi menanyakan (interogatif), fungsi menyuruh (imperative) termasuk fungsi melarang, fungsi meminta maaf, dan fungsi mengkritik (Chaer, 2010: 79-98). Berikut adalah uraian dari kelima fungsi kesantunan berbahasa tersebut.
Kalimat yang termasuk dalam kalimat deklaratif pada umumnya berfungsi untuk memberikan pernyataan tentang suatu hal. Isinya berupa informasi tanpa mengharapkan balasan atau komentar dari lawan tutur.

Fungsi menanyakan biasanya menggunakan kalimat tanya atau bersifat interrogative. Kalimat menanyakan biasanya bertujuan untuk mendapatkan respon berupa jawaban dari lawan tutur. Secara umum kalimat tanya ditandai dengan adanya tanda tanya (?).

Fungsi memerintah biasanya untuk memberikan perintah maupun suatu larangan kepada lawan tutur untuk melakukan sesuatu. Dalam bentuk lisan biasanya ditandai dengan menggunakan intonasi tinggi. Dalam bentuk tulisan biasanya ditandai dengan menggunakan tanda seru (!).

Fungsi meminta maaf biasanya dilakukan oleh penutur atau lawan tutur karena penutur atau lawan tutur merasa mempunyai kesalahan maupun melakukan tindakan yang menimbulkan ketidaknyamanan. Kalimat ini biasanya ditandai dengan menggunakan sapaan terhadap lawan tutur. Selain itu, selalu ditandai dengan adanya kata "maaf".

Fungsi mengkritik berfungsi untuk menyebutkan keburukan, kekurangan, kekeliruan, maupun kesalahan yang telah diperbuat oleh lawan tutur. Tuturan mengkritik bisa mengakibatkan dampak negatif dalam suatu komunikasi apabila tidak dilakukan dengan benar. Oleh karena 
itu, untuk menghindari mewadahi para siswa untuk ketidaksantunan dan mengungkapkan gagasan dan ketidaknyamanan lawan tutur, harus menanggapi suatu masalah yang menggunakan kalimat yang santun terdapat di sekitar. Oleh karena itu, atau kalimat berputar dan perlu adanya upaya seorang guru penyamapaian yang benar.

Fenomena ketidaksantunan mempunyai keterkaitan dengan keterampilan menulis yang berhubungan dengan pembelajaran bahasa Indonesia. Pembelajaran bahasa khususnya bahasa Indonesia telah diatur di dalam kurikulum 2013. Permasalahan keterampilan berbahasa yang masih sering terjadi pada peserta didik di sekolah adalah mengenai keterampilan menulis karena keterampilan tersebut merupakan keterampilan tertinggi dalam berbahasa. Sejauh ini, siswa hanya dibekali pengetahuan menulis secara baik dan benar. Padahal seharusnya guru menumbuhkan keterampilan menulis kepada siswa secara baik, benar, dan santun. Selaras dengan pendapat Saddhono dan Slamet (2014: 150), keterampilan menulis merupakan salah satu bentuk keterampilan berbahasa yang sangat penting bagi pembaca, di samping keterampilan menyimak, berbicara, dan membaca, baik selama mengikuti pendidikan di berbagai jenjang dan jenis sekolah maupun dalam kehidupan bermasyarakat.

Penerapan keterampilan menulis secara baik, benar, dan santun dapat dilihat dari kemampuan siswa dalam menulis teks editorial. Kegiatan menulis teks editorial merupakan suatu upaya yang dalam penggunaan sebuah bahan ajar untuk memudahkan pemahaman mengenai kesantunan berbahasa dalam menulis teks editorial. Teks editorial atau tajuk rencana merupakan artikel yang berisi opini atau pendapat penulis yang disertai alasan, fakta, dan bukti-bukti tentang permasalahan yang terjadi (Tukan, 2007: 140).

Oleh karena itu, penulis melakukan penelitian mengenai kesantunan berbahasa penulis teks editorial yang terdapat dalam tajuk rencana harian Suara Merdeka. Kegiatan menulis teks editorial berisi tentang penyampaian gagasan terhadap kondisi yang terjadi di sekitar. Oleh karena itu, setiap gagasan maupun argumen harus dituangkan dengan menggunakan bahasa yang santun sehingga proses penyampaiannya tidak merugikan maupun menyinggung pihak lain. Penerapan kesantunan berbahasa dalam rubrik tersebut layak untuk dikaji karena dapat dijadikan sebagai bahan ajar menulis teks editorial pada siswa kelas XII SMA. Hal tersebut sesuai dengan kompetensi dasar 4.6 yaitu merancang teks editorial dengan memperhatikan struktur dan kebahasaan baik secara lisan maupun tulis. Penelitian ini diharapkan mampu membantu guru untuk mewujudkan pembelajaran 
keterampilan menulis secara baik, benar, dan santun dengan menggunakan bahan ajar harian Suara Merdeka.

\section{METODE PENELITIAN}

Penelitian ini merupakan penelitian kualitatif dengan metode analisis isi. Peneliti berperan mengumpulkan data, menganalisis data berupa kata-kata tertulis, dan mengambil simpulan atas data yang telah dianalisa. Peneliti menggunakan sumber data berupa dokumen dan informan. Dokumen yang dikaji, yaitu tajuk rencana harian Suara Merdeka. Sedangkan informan, yaitu guru bahasa Indonesia SMA Negeri 1 Gemolong, siswa kelas XII SMA Negeri 1 Gemolong, dan ahli bahasa. Teknik pengumpulan data dalam penelitian kualitatif ini, yaitu wawancara dan pengkajian dokumen. Sedangkan validitas data yang digunakan dalam penelitian ini adalah triangulasi teori dan triangulasi sumber data.

\section{HASIL DAN PEMBAHASAN}

\section{Pematuhan dan Pelanggaran Maksim Kesantunan Berbahasa pada Tajuk Rencana Harian Suara Merdeka}

Data yang diperoleh dalam penelitian ini sejumlah 95 data. Pematuhan maksim kesantunan berbahasa sebanyak 35 data, pelanggaran kesantunan berbahasa sebanyak 25 data, dan fungsi kesantunan berbahasa sebanyak 35 data. Di bawah ini merupakan deskripsi data yang digunakan dalam penelitian.

Tabel 1. Pematuhan prinsip kesantunan berbahasa

\begin{tabular}{llc}
\hline No. & \multicolumn{1}{c}{ Jenis Maksim } & Jumlah \\
\hline 1. & $\begin{array}{l}\text { Maksim } \\
\text { kebijaksanaan }\end{array}$ & 6 \\
\hline 2. & $\begin{array}{l}\text { Maksim } \\
\text { kedermawanan }\end{array}$ & 8 \\
\hline 3. & Maksim penghargaan & 5 \\
\hline 4. & $\begin{array}{l}\text { Maksim } \\
\text { kesederhanaan }\end{array}$ & 1 \\
\hline 5. & Maksim pemufakatan & 5 \\
\hline 6. & Maksim kesimpatian & 19 \\
\hline & Jumlah & 35 \\
\hline
\end{tabular}

Tabel 2. Pelanggaran prinsip kesantunan berbahasa

\begin{tabular}{llc}
\hline No. & \multicolumn{1}{c}{ Jenis Maksim } & Jumlah \\
\hline 1. & $\begin{array}{l}\text { Maksim } \\
\text { kebijaksanaan }\end{array}$ & 7 \\
\hline 2. & $\begin{array}{l}\text { Maksim } \\
\text { kedermawanan }\end{array}$ & - \\
\hline 3. & Maksim penghargaan & 13 \\
\hline 4. & $\begin{array}{l}\text { Maksim } \\
\text { kesederhanaan }\end{array}$ & 3 \\
\hline 5. & Maksim pemufakatan & 2 \\
\hline 6. & Maksim kesimpatian & - \\
\hline & Jumlah & 25 \\
\hline
\end{tabular}

Tabel 3. Fungsi kesantunan berbahasa

\begin{tabular}{llc}
\hline No. & \multicolumn{1}{c}{ Jenis Fungsi } & Jumlah \\
\hline 1. & Fungsi menyatakan & 12 \\
\hline 2. & Fungsi menanyakan & 5 \\
\hline 3. & Fungsi mengkritik & 11 \\
\hline 4. & Fungsi memerintah & 7 \\
\hline 5. & $\begin{array}{l}\text { Fungsi meminta } \\
\text { maaf }\end{array}$ & - \\
\hline & Jumlah & 35 \\
\hline
\end{tabular}

Hasil penelitian terhadap kesantunan berbahasa pada tajuk rencana harian Suara Merdeka adalah sebagai berikut. 
Pematuhan Maksim Kebijaksanaan

Data (1)

"Lembaga para pemimpin perguruan tinggi ini mengimbau agar seтиa pihak, termasuk pemerintah, menahan diri dari mengeluarkan ucapan dan atau tindakan yang provokatif, agitative, serta anarkis." (Menahan Diri itu Indah; Suara Merdeka, 1 Oktober 2019)

Konteks tuturan: Tuturan tersebut mengenai kontroversi yang disebabkan oleh perubahan RUU KPK.

telah $\begin{gathered}\text { Berdasarkan data (1) penulis } \\ \text { mematuhi }\end{gathered}$

kebijaksanaan. Pematuhan maksim oleh penulis karena memberikan suatu informasi yang bertujuan untuk menyuruh lawan tutur melakukan suatu tindakan, yaitu menahan diri dari berbagai tindakan yang bersifat provokatif. Penulis menyampaikan maksud dengan ditandai dengan kata mengimbau. Penggunaan kata tersebut sebagai penanda kesantunan karena tidak bersifat memaksa lawan tutur untuk melakukan tindakan.

\section{Pematuhan Maksim Kedermawanan}

Data (2)

"Pengalaman pada periode pertama seyogyianya menempa Jokowi menjadi lebih matang dan lebih kuat dalam memimpin negara besar ini." (Menuju Indonesia Maju dan Kuat; Suara Merdeka, 21 Oktober 2019)

Konteks tuturan: Tuturan tersebut mengenai terpilihnya kembali Jokowi sebagai presiden.

Data (2) menunjukkan bahwa penulis mematuhi prinsip maksim kedermawanan. Penulis tersebut memperbesar keuntungan lawan tutur dengan memberikan saran dan harapan dengan bahasa yang santun. Saran yang diberikan penulis ditujukan pada Jokowi terkait dengan terpilihnya menjadi Presiden yang akan menjalankan kepemimpinan selama dua periode. Kesantunan tuturan tersebut terbukti dengan adanya pemakaian kata "seyogyanya" sehingga tuturan tersebut terkesan lebih halus dan santun.

\section{Pematuhan Maksim Penghargaan}

Data (3)

"Kabar optimisme terdengar dari Kabinet Indonesia Maju. Para Menteri langsung "tancap gas". Mereka langsung bergerak, bahkan sampai turun langsung ke lapangan. (Semangat Sumpah Pemuda untuk Kabinet; Suara Merdeka, 28 Oktober 2019)

Konteks tuturan: tuturan tersebut mengenai pergerakan kinerja awal para menteri Kabinet Indonesia Maju.

Penulis dalam data (3) memberikan kontribusi berupa pematuhan maksim penghargaan terhadap lawan tutur. Konteks yang dibahas mengenai kinerja para Menteri kabinet baru, yaitu Kabinet Indonesia Maju. Pematuhan maksim penghargaan ditandai dengan rasa bangga dan pujian dari penulis kepada para menteri Kabinet Indonesia Maju yang baru dilantik. 
Sebagaimana yang diketahui bahwa perubahan kabinet setiap periode selalu membawa pengaruh baik dalam hal positif maupun negatif. Pengaruh tersebut selalu menjadi sorotan di kalangan masyarakat. Kinerja masing-masing menteri diharapkan dapat memberi pengaruh positif.

Penulis dalam tuturan di atas memberikan pujian yang ditandai dengan penggalan tuturan "kabar optimisme”. Penggalan tuturan tersebut tidak hanya sebagai pujian, tetapi memiliki arti bahwa penulis berprasangka baik kepada lawan tutur. Seperti yang sudah diketahui, kinerja para menteri biasanya hanya tergencar di awal periode saja.

Dalam tuturan tersebut, penulis menaruh harap kinerja para mentari akan terus seperti itu hingga akhir periode. Cara penyampampaian penulis yang disertai dengan pujian dan prasangka baik menjadikan tuturan tersebut tergolong dalam pematuhan maksim penghargan. Oleh karena itu, tuturan tersebut dapat dikatakan santun.

\section{Pematuhan Maksim Kesederhanaan}

Data (4)

"Indonesia dikaruniai seorang pemimpin yang baik dan bersih, dengan didampingi oleh seorang ulama. Ini adalah berkah yang luar biasa bagi Indonesia untuk mencapai taraf negara maju dan berwibawa." (Menuju Indonesia Maju dan Kuat; Suara Merdeka, 21 Oktober 2019)
Konteks tuturan: tuturan tersebut merupakan pengungkapan kekaguman dan harapan terhadap pemimpin baru Indonesia.

Penulis dalam data (4) telah mematuhi maksim kesederhanaan terhadap lawan tutur. Penulis membahas tentang pemimpin baru yang terpilih di Indonesia. Pematuhan maksim kesederhanaan dalam tuturan tersebut ditandai dengan adanya ungkapan rasa syukur dari penulis terhadap pemimpin baru. Penggalan tuturan "Ini adalah berkah yang luar biasa bagi Indonesia" merupakan bukti penanda bahwa tuturan tersebut penulis

\section{Pematuhan Maksim Pemufakatan}

Data (5)

"Kita bersepakat, dalam situasi apapun, tanpa jaminan keamanan sulit meraih kesejahteraan. Keamanan dan kesejahteraan akan meningkat dengan adanya sinergitas TNI bersama Polri dan masyarakat." (Wujudkan TNI Professional dan Membanggakan; Suara Merdeka, 5 Oktober 2019)

Konteks tuturan: tuturan tersebut tentang kinerja TNI bersama masyarakat dalam menjaga stabilitas NKRI.

$$
\text { Penulis dalam data }
$$
termasuk dalam kategori mematuhi maksim pemufakatan. Konteks yang dibahas mengenai kolaborasi antara TNI bersama polri dan masyarakat dalam menjaga stabilitas keamanan NKRI. Penulis memaksimalkan kesepakatan dengan lawan tutur. 
Bukti kesepakatan ditandai dengan kata "sepakat" yang diungkapkan penulis. Kata "bersepakat" memiliki arti kesetujuan terhadaap suatu hal. Selain itu, penulis menggunakan penunjuk persona "kita" yang berarti penulis termasuk di dalam kesepakatan tersebut.

\section{Pematuhan Maksim Kesimpatian}

Data (6)

"Patut disayangkan jika segala seruan "menahan diri" dianggap sebagai pelemahan terhadap perjuangan mahasiswa atau pelajar." (Menahan Diri itu Indah; Suara Merdeka, 1 Oktober 2019)

Konteks tuturan: tuturan tersebut mengenai pelaksanaan demokrasi para mahasiswa atau pelajar terhadap pemerintah.

Data (6) merupakan bentuk pematuhan maksim kesimpatian oleh penulis. Pematuhan prinsip kesimpatian ditunjukkan penulis terhadap mahasiswa atau pelajar karena dalam masyarakat sebagian besar menganggap bahwa seruan "menahan diri" tersebut melemahkan perjuangan mahasiswa atau pelajar dalam melaksanakan demokrasi. Padahal seruan "menahan diri" sesungguhnya sebagai himbauan kepada seluruh masyarakat agar dalam pelaksanaan maupun penegakan demokrasi dilaksanakan dengan sebagaimana semestinya dan diharapkan tidak merugikan pihak manapun.
Rasa simpati penulis ditandai dengan adanya ungkapan "patut disayangkan". Penulis menunjukkan rasa simpati dengan berusaha meluruskan arti dari seruan "menahan diri" tersebut. Selain menunjukkan rasa simpati, tuturan tersebut juga memaksimalkan

\section{Pelanggaran Maksim Kebijaksanaan}

Data (7)

"Pesan yang tersampaikan dari Kabinet Indonesia Maju adalah bahwa mereka siap bergerak dan berlari cepat. Pesan itu tentu harus ditangkap juga oleh seluruh jajaran di bawahnya. Justru, inilah problem terbesar bagi bangsa ini." (Semangat Sumpah Pemuda untuk Kabinet; Suara Merdeka, 28 Oktober 2019)

Konteks tuturan: Pesan untuk Kabinet Indonesia Maju.

Permasalahan yang dipaparkan dalam tajuk rencana tersebut mengenai semangat sumpah pemuda untuk kabinet. Kabinet terbaru ini diharapkan mampu bergerak cepat dalam menyikapi segala permasalahan yang terjadi di negeri ini. Kegesitan kabinet dalam bekerja merupakan prasyarat mutlak untuk mencapai tujuan ketika negara lain sudah berlari terlebih dahulu. Kegesitan kabinet sebaiknya juga ditangkap oleh jajaran di bawahnya untuk bersinergi bersama bekerja untuk rakyat.

Data (7) menunjukkan bahwa penulis memberikan kontribusi yang telah melanggar maksim 
kebijaksanaan terhadap lawan tutur. Konteks yang dibahas adalah tentang pesan yang disampaikan kepada seluruh jajaran dalam Kabinet Indonesia Maju. Pelanggaran maksim kebijaksanaan ditandai dengan adanya tuturan yang bersifat memaksa dari penulis kepada lawan tutur.

Pernyataan itu ditandai dengan penggunaan kata "harus" yang mengakibatkan tidak adanya pilihan lain lawan tutur untuk melakukan tindakan. Pelanggaran maksim kebijaksanaan yang dilakukan oleh penulis sebenarnya memiliki maksud agar jajaran Kabinet Indonesia Maju untuk lebih baik dari kabinet sebelumnya sehingga mampu membawa Indonesia menjadi lebih baik. Jadi, penulis bermaksud untuk memberikan nasihat para jajaran Kabinet Indonesia Maju.

\section{Pelanggaran Maksim Penghargaan}

Data (8)

"Pada sisi lain, penepatan RUU KPK secepat kilat itu membawa cita DPR di mata publik makin terpuruk." (Cerminan Ketertiban Aksi Buruh; Suara Merdeka, 4 Oktober 2019)

Konteks tuturan: Penetapan RUU KPK oleh DPR yang dianggap tidak sesuai dengan aturan.

Penulis dalam data (8) telah melanggar maksim penghargaan karena mengecam lawan tutur secara langsung di hadapan umum. Pelanggaran itu tampak pada tuturan "di mata publik makin terpuruk". Penyampaian maksud penulis untuk mengkritik yang jelas ditujukan kepada DPR akibat perubahan RUU KPK secara kilat. Namun, tuturan tersebut sangat keras dan memojokkan lawan tutur, yaitu DPR. Tuturan seperti itu menunjukkan ketidaksantunan karena penulis terkesan jengkel dan tidak menyukai lawan tutur.

\section{Pelanggaran MaksimKesederhanaan}

Data (9)

"Ketika banyak dibicarakan tentang disrupsi dan keguncangan digital, banyak orang lupa bahwa sesungguhnya yang harus berubah lebih dahulu adalah cara pandang dan cara pikir manusia Indonesia dari kekangan konservatisme menjadi digitalis modern." (Semangat Sumpah Pemuda untuk Kabinet; Suara Merdeka, 28 Oktober 2019)

Konteks tuturan: Semangat pendobrakan Kabinet Indonesia Maju yang diharapkan mampu mengubah cara pandang dan cara pikir manusia di Indonesia.

Penulis dalam data merupakan bentuk pelanggaran maksim kesederhanaan karena tuturan tersebut termasuk memaksimalkan pujian pada diri sendiri. Tuturan penulis mempunyai maksud tersirat bahwa seakan-akan penulis mengetahui bahwa banyak orang yang lupa mengenai cara pandang dan cara pikir. Padahal penulis juga belum tentu mengetahui terlebih dahulu dan belum tentu telah melakukan hal tersebut. Penulis seolah-olah 
mengetahui semua tentang hal tersebut sehingga dianggap memaksimalkan pujian pada diri sendiri dan termasuk melanggar kesantunan berbahasa.

\section{Pelanggaran Maksim Pemufakatan}

Data (10)

"Apakah publik puas pada kabinet baru? Tidak sepenuhnya puas. Kabinet ini dianggap terlalu kompromi sehingga musuh politik pun dijadikan bagian kekuatan." (Kontroversi Kabinet Warnawarni; Suara Merdeka, 24 Oktober 2019)

Konteks tuturan: pertanyaan yang diangkat oleh penulis mengenai kabinet baru yang di dalamnya terdapat musuh politik.

Data (10) tersebut merupakan tuturan yang melanggar maksim pemufakatan. Pelanggaran tersebut karena tuturan mengandung maksud menyangkal terkait dengan kepuasan publik pada kabinet baru. Penulis tidak setuju, menurut penulis Kabinet Indonesia Maju tidak memuaskan karena kabinet tersebut terlalu kompromi hingga musuh menjadi bagian kekuatan politik. Hal tersebut diperjelas dengan tuturan penulis Apakah publik puas padaa kabinet baru? Tidak sepenuhnya puas.

\section{Fungsi Kesantunan Berbahasa pada Tajuk rencana Harian Suara Merdeka}

\section{Fungsi Menyatakan}

Data (11)
"Namun bagi rakyat, peristiwa pelantikan Presiden Joko Widodo dan Wakil Presiden Ma'ruf Amin adalah peristiwa sejarah dan kegembiraan. Semoga, rasa kebahagiaan itu pula yang dirasakan oleh seluruh warga masyarakat, terlepas dari latar belakang dan afiliasi masingmasing warga." (Menyambut Pelantikan Pemimpin Baru; Suara Merdeka, 19 Oktober 2019)

Konteks tuturan: Kegembiraan masyarakat terkait peristiwa pelantikan Presiden Joko Widodo dan Wakil Presiden Ma'ruf Amin

$$
\text { Tuturan dalam data }
$$

merupakan tuturan penulis yang merupakan pernyataan kesenangan. Penulis menyatakan kesenangan masyarakat dalam pelaksanaan pelantikan Presiden dan Wakil Presiden terbaru. Rasa kesenangan ditandai dalam kutipan Namun bagi rakyat, peristiwa pelantikan Presiden Joko Widodo dan Wakil Presiden Ma'ruf Amin adalah peristiwa sejarah dan kegembiraan. Pernyataan kesenangan penulis menjadikan tuturan tersebut santun sekaligus tidak merugikan pihak manapun.

\section{Fungsi Menanyakan}

Data (12)

"Lima menteri ekonomi langsung menggelar Rapat Koordinasi soal Destinasi Pariwisata Prioritas, di Gedung Kementerian PUPR, Jakarta. Beberapa menteri bahkan langsung kunjungan ke Lapangan. 
Gerak cepat dan kesigapan para menteri semoga tidak hanya pada periode awal saja." (Semangat Sumpah Pemuda Untuk Kabinet; Suara Merdeka, 28 Oktober 2019) Konteks tuturan: Lima menteri baru yang bergerak cepat dan sigap di awal periode.

Tuturan pada data merupakan sebuah wujud pertanyaan yang berfungsi untuk menanyakan suatu kebenaran tentang sebuah tindakan. Tindakan yang dipertanyakan, yaitu mengenai kegiatan demonstrasi. Dalam kalimat tanya tersebut oleh penulis yang ditujukan kepada lawan tutur, akan tetapi penutur secara langsung memberikan jawaban. Tuturan tersebut dapat dikatakan santun karena penggunaan bahasa yang halus sehingga mampu diterima dengan baik oleh lawan tutur. Selain itu, konteks dalam tuturan membahas mengenai demonstrasi, sedangkan kegiatan demonstrasi memang diperbolehkan asalkan sesuai dengan prosedur. Dengan demikian, jawaban penutur pun sudah tepat dengan konteks yang dibicarakan.

\section{Fungsi Memerintah}

Data (13)

"Apakah demonstrasi tidak diperbolehkan? Tentu saja boleh."

(Menahan Diri itu Indah; Suara

Merdeka, 1 Oktober 2019)

Konteks tuturan: Pelaksanaan demokrasi mengenai Perubahan RUU KPK yang dilakukan DPR secara kilat.
Tuturan penulis dalam data (13) sebenarnya bermaksud menyuruh lawan tutur untuk melakukan tindakan. Hal tersebut ditunjukkan pada kutipan tuturan semoga tidak hanya pada periode awal saja. Doa harapan yang disampaikan oleh penulis bukan hanya sekadar doa. Namun, penulis menghendaki agar para menteri untuk terus bergerak cepat dan sigap selama periode berlangsung karena sejauh ini para menteri kabinet-kabinet lalu hanya semangat di awal periode saja.

\section{Fungsi Mengkritik}

Data 14

"Kita melihat lima tahun terakhir banyak unsur dari eksekutif, legislatif, dan yudikatif terjerat dalam perkara hukum. Penangkapan pejabat oleh KPK tak lagi mengejutkan publik, seperti peristiwa wajar." (Instruksi Memerangi Perilaku Korupsi; Suara Merdeka, 25 Oktober 2019)

Konteks tuturan: Peristiwa penangkapan pejabat publik yang sering terjadi oleh KPK.

Tuturan pada data berfungsi untuk menyebutkan keburukan. Keburukan ditujukan pada permasalahan mengenai pejabat publik. Penutur menyampaikan kesalahan tersebut disertai dengan solusi yang seharusnya diterapkan oleh lawan tutur. Penyampaian dapat dikatakan santun karena penggunaan kata "sejatinya" yang merupakan bentuk pemilihan bahasa yang halus untuk memberikan solusi tanpa 
menyudutkan pihak lain.

\section{Relevansi Kesantunan Berbahasa pada Tajuk Rencana Harian Suara Merdeka sebagai Bahan Ajar Menulis Teks Editorial Siswa Kelas XII SMA}

Bahan ajar merupakan seperangkat pembelajaran yang berisi materi pembelajaran sesuai dengan kompetensi dasar yang akan dicapai serta bertujuan untuk memudahkan peserta didik untuk memahami materi pembelajaran. Menurut Prastowo (2011: 58) terdapat tiga kriteria bahan ajar yang baik. Pertama, prinsip relevansi yang artinya bahan ajar seharusnya relevan dengan standar kompetensi maupun kompetensi dasar. Kedua, konsistensi yang berarti bahan ajar memiliki nilai keajegan. Ketiga, kecukupan yang berarti bahan ajar yang dipilih sebiknya memadai dalam membantu siswa menguasai kompetensi dasar.

Penelitian kesantunan

berbahasa pada tajuk rencana harian Suara Merdeka ini memiliki relevansi dengan pembelajaran menulis teks editorial di SMA. Berikut adalah rincian $\mathrm{KD}$ pembelajaran menulis teks editorial di Kelas XII SMA semester gasal.
Tabel 5. Kompetensi Dasar tentang Teks Editorial dan Materi Pokok

\begin{tabular}{llcl}
\hline \multicolumn{2}{c}{ Kompetensi Dasar } & Materi Pokok \\
\hline 4.6 & Merancang teks & Teks Editorial: \\
& editorial dengan & $\bullet$ & struktur; \\
memerhatikan & $\bullet$ & unsur \\
struktur dan & & kebahasa \\
kebahasaan baik & & an; \\
secara lisan & $\bullet$ & topik; dan \\
maupun tulis & $\bullet$ & kerangka \\
& & karangan
\end{tabular}

Peneliti telah melakukan wawancara dengan ahli bahasa, guru bahasa Indonesia kelas XII di SMA Negeri 1 Gemolong, dan siswa kelas XII SMA N 1 Gemolong berkaitan dengan manfaat tajuk rencana harian Suara Merdeka sebagai bahan ajar menulis teks editorial siswa kelas XII SMA.

Tajuk rencana harian Suara Merdeka layak dijadikan sebagai bahan ajar pembelajaran menulis teks editorial. Tajuk rencana harian Suara Merdeka sudah mematuhi kode etik jurnalistik, penulisan yang baik dan benar, dan penggunaan bahasa santun. Selain itu, pemilihan bahan ajar juga perlu memperhatikan pemakaian bahasa yang mematuhi PUEBI, pemilihan diksi yang tepat, mengandung makna yang mendidik, dan sesuai dengan KI dan KD.

Guru Bahasa Indonesia Kelas XII SMA Negeri 1 Gemolong menjelaskan bahwa tajuk rencana harian Suara Merdeka tersebut dapat dijadikan sebagai bahan ajar dalam pembelajaran menulis teks editorial. Pemilihan tajuk tentu dengan berbagai pertimbangan, yaitu yang pertama, harus dipilih kesesuaian isi 
dari tajuk rencana, yang kedua, muatan atau strukturnya, dan yang ketiga, penggunaan bahasanya. Selain itu, Pemilihan tajuk dengan berbagai pertimbangan, yaitu bahasa jelas, ulasan tajam, dan materi berbobot. Oleh karena itu, tajuk rencana harian Suara Merdeka dapat dijadikan sebagai bahan ajar menulis teks editorial dengan berbagai pertimbangan serta relevan dengan kompetensi dasar yang ada di jenjang SMA.

Sehubungan dengan pembahasan tersebut, tajuk rencana harian Suara Merdeka dapat dijadikan sebagai bahan ajar dengan memberikan pengalaman langsung kepada siswa yang diterapkan dengan beberapa tahapan.

Tahapan tersebut berkaitan pada pembelajaran dengan pendekatan saintifik. Pembelajaran dengan pendekatan saintifik menuntut siswa untuk berpikir kritis dan menemukan permasalahan yang nanti perlu dikomunikasikan. Dalam kaitannya pembelajaran dengan pendekatan saintifik, hasil penelitian Agustian (2017) menyatakan bahwa pembelajaran bahasa Indonesia dengan pendekatan saintifik berbasis teks menjadikan siswa dapat berlatih untuk berpikir secara metodologis, yang merupakan sebuah kemampuan berpikir yang akan dibutuhkan pada masa yang akan datang, siswa mampu mengembangkan kemampuan membaca pemahaman, serta kemampuan dalam menulis akan berkembang semakin baik.
Berdasarkan paparan tersebut, kemampuan siswa dalam menulis teks editorial memerlukan pemahaman kesantunan dalam berbahasa. Kemampuan penggunaan kesantunan berbahasa dalam penyampaian argumen akan menjadi ciri karakter yang tertanam dalam diri siswa. Dengan demikian, hasil penelitian ini menunjukkan siswa yang memiliki kemampuan mengungkapkan argumen dengan memperhatikan kesantunan berbahasa, maka juga mampu menulis teks editorial dengan baik.

\section{SIMPULAN}

Dari beberapa pematuhan maksim kesantunan berbahasa, yang paling banyak ditemukan adalah pematuhan terhadap maksim kesimpatian. Di samping itu, dalam harian Suara Merdeka juga ditemukan bentuk-bentuk pelanggaran kesantunan berbahasa. Bentuk pelanggaran kesantunan berbahasa yang paling banyak ditemukan, yaitu pelanggaran maksim penghargaan.

Fungsi kesantunan berbahasa dalam tajuk rencana harian Suara Merdeka ditunjukkan dengan penggunaan bahasa yang santun dalam menyampaikan argumen. Fungsi kesantunan yang paling banyak ditemukan, yaitu fungsi menyatakan. Sedangkan fungsi yang tidak ditemukan, yaitu fungsi meminta maaf.

Tajuk rencana harian Suara Merdeka memiliki potensi untuk 
digunakan sebagai bahan ajar menulis teks editorial siswa kelas XII SMA. Hal tersebut dikarenakan tajuk rencana harian Suara Merdeka sesuai dengan kompetensi dasar, yaitu menulis teks editorial. Dalam menulis teks editorial, siswa membutuhkan bahan ajar yang sesuai dengan kompetensi dasar yang akan dicapai. Tajuk rencana harian Suara Merdeka sesuai dengan struktur dan kaidah kebahasaan pada teks editorial. Penggunaan tajuk rencana tersebut dapat menunjang siswa untuk meningkatkan pemahaman terhadap pembelajaran menulis teks editorial.

\section{REFERENSI}

Agustina, E.S. (2017). Pembelajaran Bahasa Indonesia Berbasis Teks: Representasi Kurikulum 2013. Jurnal Bahasa dan Sastra, 18(1), 84-99.

Chaer, A. (2010). Kesantunan Berbahasa. Jakarta: Rineka Cipta.

Leech, G.N. (2011). Prinsip-prinsip Pragmatik. Terj M.D.D Oka. Jakarta: UI Press.

Mahmud, M., Abduh, A., \& Akil, M. (2019). Promoting a Balance of Harmony and Authority in Indonesian Research Seminars Through Politeness Strategis. European Scientific Language Journal, 12(2), 80-98.

Pranowo. (2012). Berbahasa Secara Santun. Yogyakarta: Pustaka pelajar.

Prastowo, A. (2012). Panduan Kreatif Membuat Bahan Ajar Inovatif. Yogyakarta: Diva Press.
Rahardi, K. (2005). Pragmatik: Kesantunan Imperatif Bahasa Indonesia. Jakarta: Penerbit Erlangga.

Rahardi, K., Setyaningsih, Y., \& Dewi, R.P. (2018). Pragmatik: Fenomena Ketidaksantunan Berbahasa. Jakarta: Penerbit Erlangga.

Saddhono, K. \& Slamet. (2014). Pembelajaran Keterampilan Berbahasa Indonesia. Yogyakarta: Graha Ilmu.

Tukan, P. (2007). Mahir Berbahasa Indonesia 2. Jakarta: Yudhistira. 